\title{
G Protein-Coupled Receptors in Cancer
}

\author{
Rachel Bar-Shavit ${ }^{1, *}$, Myriam Maoz ${ }^{1}$, Arun Kancharla ${ }^{1}$, Jeetendra Kumar Nag ${ }^{1}$, \\ Daniel Agranovich ${ }^{1}$, Sorina Grisaru-Granovsky ${ }^{2}$ and Beatrice Uziely ${ }^{1}$
}

1 Sharett Institute of Oncology, Hadassah-Hebrew University Medical Center, Jerusalem 91120, Israel; Myriamm@hadassah.org.il (M.M.); kancharlarn@gmail.com (A.K.); jeetendr.nag@mail.huji.ac.il (J.K.N.); Danyaag@gmail.com (D.A.); Beatrice@hadassah.org.il (B.U.)

2 Department of Obstetrics and Gynecology, Shaare-Zedek Medical Center, Jerusalem 91031, Israel; sorina@szmc.org.il

* Correspondence: Rachelbar@ekmd.huji.ac.il; Tel.: +972-2-677-7563; Fax: +972-2-642-7485

Academic Editors: Kathleen Van Craenenbroeck and Gregor Drummen

Received: 6 June 2016; Accepted: 8 August 2016; Published: 12 August 2016

\begin{abstract}
Despite the fact that G protein-coupled receptors (GPCRs) are the largest signal-conveying receptor family and mediate many physiological processes, their role in tumor biology is underappreciated. Numerous lines of evidence now associate GPCRs and their downstream signaling targets in cancer growth and development. Indeed, GPCRs control many features of tumorigenesis, including immune cell-mediated functions, proliferation, invasion and survival at the secondary site. Technological advances have further substantiated GPCR modifications in human tumors. Among these are point mutations, gene overexpression, GPCR silencing by promoter methylation and the number of gene copies. At this point, it is imperative to elucidate specific signaling pathways of "cancer driver" GPCRs. Emerging data on GPCR biology point to functional selectivity and "biased agonism"; hence, there is a diminishing enthusiasm for the concept of "one drug per GPCR target" and increasing interest in the identification of several drug options. Therefore, determining the appropriate context-dependent conformation of a functional GPCR as well as the contribution of GPCR alterations to cancer development remain significant challenges for the discovery of dominant cancer genes and the development of targeted therapeutics.
\end{abstract}

Keywords: G protein-coupled receptors (GPCRs); protease; protease-activated receptor; protease-activated receptors (PARs); PH-domain; oncogenes; cancer; LPA(1-6); CXCR4; Wnt/ $\beta$-catenin; Hippo/YAP

\section{Introduction}

G protein-coupled receptors (GPCRs) comprise the largest family of cell surface receptors in the human genome, regulating a plethora of physiological responses and serving as frequent drug targets. Despite their broad physiological functions and associated disease processes, which have resulted in their designation as favorable sites for pharmacological drug development, their role in tumor biology is underappreciated. Conformational changes take place after ligand binding, inducing the activation of complex signaling schemes that in turn lead to a cell response. Canonical GPCR agonist activation involves the recruitment of $G$ proteins followed by the phosphorylation of the receptor by $G$ protein-coupled receptor kinase (GRK), "allowing" the binding of $\beta$-arrestin 1 and 2 (e.g., referring to arrestin 2, the first non-visual arrestin, and 3 (the second cloned non-visual arrestin), respectively) and subsequent internalization into endosomes. Internalized receptors can either recycle back to the cell surface or undergo degradation. In the past, the "two-state" receptor model (inactive and active states) was widely accepted to explain GPCR function; however, a more intricate and complex "multi-state" model entailing high GPCR conformational dynamics is now favored. GPCRs are pleiotropic with respect to the cell signal proteins they activate within a cell, and therefore more than one conformation 
of a receptor exists. Hence, different ligands can induce distinct receptor conformational states following activation, initiating several specific downstream signaling profiles. Several conformational changes in a single GPCR, eliciting discrete signaling pathways, is termed "biased agonism" [1-4]. As an example, it has been demonstrated that, in addition to regulating the GPCR signaling that induces internalization and desensitization, $\beta$-arrestin 1 and 2 are also capable of initiating distinct signals on their own [5]. For example, in the activation of the endothelin receptor (ETA) receptor via endothelin (ET-1/ET $\mathrm{A} R$ ) in epithelial ovarian cancer, $\beta$-arrestin 1 is required to maintain $\mathrm{NF} K \mathrm{~B}$ transcriptional activity in response to endothelin receptor $\mathrm{A}\left(\mathrm{ET}_{\mathrm{A}} \mathrm{R}\right)$ activation. In addition, in response to $\mathrm{ET}_{\mathrm{A}} \mathrm{R}$ activation (via ET-1), $\beta$-arrestin 1 increases its nuclear localization and binds to nuclear $\beta$-catenin, thereby enhancing $\beta$-catenin transcriptional activity, a central path in ovarian cancer $[6,7]$.

Four main groups of GPCRs are recognized and classified according to their pharmacological properties by the guidelines of the International Union of Basic and Clinical Pharmacology: Class A is rhodopsin-like; Class B is secretin-like; Class C is comprised of metabotropic glutamate/pheromone; and Class D is comprised of frizzled receptors. Class A is the largest and best-studied family, and includes several members that play a major part in tumor biology, for example protease-activated receptors, or protease-activated receptors (PARs). Class A has been further subdivided into four groups: $\alpha, \beta, \gamma$, and $\delta$. The $\delta$ group contains, among others, the leucine-rich repeat-containing receptors (LGRs) including LGR5, a bona fide stem cell marker for colon and breast tissues.

While GPCRs regulate many aspects of tumorigenesis as well as many cancer-associated signaling pathways [8,9], only a few drugs aiming to inhibit GPCRs are currently used in cancer. Genome-wide major analyses of multiple human tumors have exposed novel GPCRs that are modified in cancer and might be potential candidates for cancer drug development. Importantly, it is imperative to differentiate between cancer driver genes and bystanders to identify valid targets for personalized medicine in the future. Indeed, pharmacological treatments targeting GPCRs will become increasingly attractive as more data associating GPCRs with cancer emerges. Understanding the molecular machinery of GPCRs in tumor development may contribute to tumor-related GPCR drug development. In this review we discuss recent advances in cancer-associated GPCRs and signal proteins such PARs, chemokine receptors, G $\alpha 12 / 13$ proteins, lysophosphatidic acid (LPA), and GPCR-mediated pathways such as the WNT and Hippo signaling pathways. We also describe potential drug design targets such as the pleckstrin-homology $(\mathrm{PH})$ binding motifs that were found and characterized in PAR-implicated tumor biology.

\section{Biasing towards Specific G-Proteins in Cancer}

The structural signature of seven transmembrane domains that couple to $G$ proteins for signaling are among the common themes in GPCRs. G proteins are divided into four main sub-groups: G $\alpha$, $\mathrm{G} \alpha \mathrm{q} / 11, \mathrm{G} \alpha \mathrm{i} / \mathrm{o}$ and $\mathrm{G} \alpha 12 / 13$ which are associated selectively, upon ligand activation, to initiate a potential downstream signaling pathway. $G$ proteins are composed of three subunits, $G \alpha, G \beta$ and $G \gamma$ which are located in the inner part of the plasma membrane. Upon ligand binding the signal is transmitted through conformational changes, which consequently result in the initiation of the $G$ protein cycle of association. In fact, GPCRs function as guanine nucleotide exchange factors for $\alpha$ subunit of the G protein, promoting the exchange of bound GDP for GTP- $\alpha$. Bound GTP- $\alpha$ allows the switch from an inactive state (of the bound trimeric $G$ proteins) to an active status of the GTP- $\alpha$ subunit and the release of $\beta \gamma$ subunits. These $\beta \gamma$ subunits consequently activate downstream signaling partners such as Src, phospholipase $C$, adenylyl cyclase, phosphodiesterases and ion channels. The cycle is terminated by the hydrolysis of $\alpha$ subunit-bound GTP to GDP, and its re-association with $\beta \gamma \mathrm{G}$ proteins for turning off the signal.

A significant feature of a biased GPCR ligand is the ability to activate either of the G protein subfamilies, $G \alpha s, G \alpha q / 11, G \alpha i / o$ or $G \alpha 12 / 13$, for selectively harnessing and recruiting a specifically selected downstream signal pathway. While most of the $G$ proteins are not associated with cancer, the $G \alpha 12 / 13$ family is connected with cell transformation (e.g., fibroblasts) [10,11], thus directing 
toward tumor-related processes. G $\alpha 12 / 13$ family members may be also involved in the control of the Rho-dependent formation of stress fibers, the Jun kinase/stress-activated protein kinase pathway, and the $\mathrm{Na}^{+} / \mathrm{H}^{+}$exchanger [12-14].

Genetic ablation of $\mathrm{G} \alpha 13$ in mice results in embryonic lethality at a stage when gastrulation is already completed (about embryonic day 9.5). On the other hand, the ablation of $G \alpha 12$, the other family member, results in viable mice exhibiting a normal phenotype. This genetic outcome points to distinct roles of the $G \alpha 12 / 13$ family members. In addition, a defective assembly of the vascular system, which is prominent mostly in the yolk sac and in the head mesenchyme, was also demonstrated in G $\alpha 13-$ deficient mouse embryos [15].

LPA receptors are coupled to $\mathrm{G} \alpha \mathrm{q} / 11, \mathrm{G} \alpha \mathrm{i}$ and $\mathrm{G} \alpha 12 / 13$ [16-18]. In NIH 3T3 and neuroblastoma B103 cells, the LPA3 receptor is coupled to G $\alpha$ i, leading to Ras-GTP accumulation of mitogen-activated protein kinase (MAPK) activation and enhanced cell proliferation [19,20]. LPA1, LPA2 and LPA3 receptors in PC12 cells are coupled to $\mathrm{G} \alpha \mathrm{q} / 11$ following neurokinin A or endothelin binding to these receptors, thereby inducing signaling via tyrosine kinase $c$-Src but not Ras and $\beta$-catenin via $\beta$-arrestin $1[7,21]$. Other examples in PC12 cells demonstrate that LPA1-3 binds to G $\alpha 12 / 13$ [22]

$G$ proteins may direct biased agonism also in various metabolic disease systems (other than cancer) as for example, coupling of GPR109A to Gai/o, following biased ligand activation, leading to induced levels of high-density lipoprotein and consequently to a decrease in triacylglycerol levels. As a result it leads to a significant decrease in cardiovascular morbidity and mortality [23]. Protease-activated receptor $1\left(\mathrm{PAR}_{1}\right)$ as a member of the GPCR family, binds also to various heterotrimeric $\mathrm{G}$ protein subtypes within a cell, promoting different cellular functions. For example, as recently elegantly demonstrated, N-linked glycosylation of $\mathrm{PAR}_{1}$ at extracellular loop 2 (ECL2) favors coupling to G $\alpha 12 / 13$-dependent Rho activation. In contrast, a mutant form lacking in glycosylation at the ECL2 region couples more efficiently to G $\alpha q$, mediating phosphoinositide (PI) signaling [24]. Traditionally,

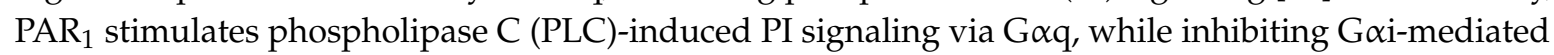
adenylate cyclase signaling. Biased agonism could activate not only different $\mathrm{G}$ protein subtypes, but also stimulate an alternate system to $G$ proteins as signaling transducers, such as $\beta$-arrestins [25]. The $\beta$-arrestin bias may, in some cases, confer positive effects and rather than mediating internalization and degradation, ir directs the recruitment, activation, and scaffolding of cytoplasmic signaling complexes via $\beta$-arrestins 1 and 2. For example, a $\beta$-arrestin-biased ligand, PTH (parathyroid hormone), promotes bone formation and homeostasis, thus reducing hypercalcemia of malignancy and osteoporosis [26]. Nevertheless, the molecular mechanism of biased ligands between $\beta$-arrestin and the $G$ protein pathways are not yet known. $\beta$-arrestin has also been shown as critical for Wnt/ $\beta$-catenin signal transduction. The axis of Dishevelled (DVL)- $\beta$-arrestin interaction is important for the Wnt/ $\beta$-catenin signaling. It has been demonstrated that in mouse embryonic fibroblasts (MEFs), genetic ablation of $\beta$-arrestin 1 and/or 2 impairs wnt-3A-induced activation of DVL and $\beta$-catenin signaling [27]. In ovarian cancer the activation of the endothelin-A receptor $\left(\mathrm{ET}_{\mathrm{A}} \mathrm{R}\right)$ by endothelin-1 (ET-1) plays a central role in ovarian cancer progression. Silencing of both $\beta$-arrestin 1 and $\beta$-arrestin 2 inhibits these receptors' (e.g., $\mathrm{ET}_{\mathrm{A}} \mathrm{R}$ ) signaling, reducing, among others, Src and serine/threonine kinase Akt (AKT) activation finally affecting the $\beta$-catenin pathway [28].

\section{G Protein-Coupled Receptor (GPCR) and Oncogenicity}

The first link between cellular transformation and GPCRs was discovered in 1986 with the identification of the MAS oncogene [29]. The mas gene product exhibits properties characteristic of GPCRs, including seven pass of the membrane, and is made up of 325 amino acids. MAS is the receptor for the metabolite angiotensin-(1-7) (Ang-(1-7)), which is formed by angiotensin-converting enzyme 2 on angiotensin II and functions as a vasodilator and antiproliferative agent [30]. Using a cDNA expression library screen for oncogenes revealed two other GPCRs with oncogenic properties, namely G2A and PAR 1 . The role of the PAR family (whereby PAR ${ }_{1}$ is the first and prototype member) in cancer biology will be discussed below. 
Another oncogene, G2A, was independently identified by Kay and colleagues [31] and Witte et al., [32]. They showed [31] that forced expression of G2A in NIH3T3 cells led to an increased number of cells in the G2/M cell-cycle phase; therefore, they identified this gene as G2A (G2 accumulation). In addition, overexpression of G2A antagonized the activity of Bcr-Abl in Rat-1 fibroblasts and in mouse bone marrow cells, inducing increased cell proliferation. Therefore, G2A may either promote or antagonize growth, depending on the cellular context. G2A mRNA is expressed most often in hematopoietic tissue and cell lines. No mutations were found in G2A and no known ligand for G2A has been identified. It is not yet known whether G2A transformation is ligand-independent or takes place as a consequence of an unknown serum ligand or a NIH3T3 cell-residing ligand.

Whitehead and co-workers identified $\mathrm{PAR}_{1}$, which encodes the prototype member of the PAR family. Using the anchorage-independent foci formation assay in NIH3T3 cells, they demonstrated in two independent screens $[33,34]$ that overexpression of naïve human $\mathrm{PAR}_{1}$ caused a similar transforming activity; both loss of anchorage- and serum-dependent growth were observed in NIH $3 \mathrm{~T} 3$ cells with $\mathrm{PAR}_{1}$ overexpression. This activity was described in addition to its potent foci-forming activities. We have demonstrated that $\mathrm{PAR}_{1}$ overexpression induces invasion in pathological cancer cells as well as in the physiological invasion process of placenta implantation into the uterus deciduas [35]. Significantly, no mutations have been found in any of the PAR family members. Its transforming activity is attributed to receptor overexpression in malignant epithelial cells as compared to no expression in normal epithelium. It is postulated that PAR-transforming activities are ligand-dependent, and that they are seen in correlation with the plethora of serine-protease present in the dynamic milieu of a tumor microenvironment.

\section{Gep Oncogenes}

Members of the $G \alpha 12$ family, $G \alpha 12$ and $G \alpha 13$, were isolated at first as the gep oncogenes with transforming capabilities $[10,36]$. These $G$ proteins regulate various cellular processes, among which are migration, proliferation, transformation, platelet aggregation, neurite retraction, and actin-stress fiber formation [37-39]. $G \alpha 12$ and $G \alpha 13$ belong to the large family of $G$ proteins consisting of $\alpha, \beta$, and $\gamma$ subunits. They induce signals from GPCRs to intracellular effectors [40-42]. The $\alpha$-subunit is a protein of $37-42 \mathrm{kDa}$ including the guanine nucleotide-binding site and the intrinsic GTPase activity. Ligand-activated GPCRs catalyze the exchange of bound GDP to GTP in the $\alpha$ subunit. GTP-bound subunits stimulate distinct downstream effectors. A constitutively activated mutant of $\mathrm{G} \alpha_{12}\left(\mathrm{G} \alpha_{12} \mathrm{QL}\right)$, as well as $\mathrm{G} \alpha_{13} \mathrm{QL}$, effectively transform NIH3T3 fibroblasts, as determined via foci-forming activities [43-45]. They also control small GTP-binding proteins (i.e., the Ras and Rho family) and have an impact on the activity of several transcription factors such as serum response factor (SRF), activating protein 1 (AP-1), the nuclear factor of activated T cells (NFAT), a signal transducer and activator of transcription 3 (STAT3), and nuclear factor-kB [46-49]. The small GTPases Rho and Rac play critical roles in communicating $\mathrm{G} \alpha 12 / \mathrm{G} \alpha 13$ signaling through the Rho family of GTPases [47,48]. Indeed, GPCR ligands such as thrombin, LPA, and S1P are involved in stimulating tumor growth and invasion via coupling of their cognate receptors to $\mathrm{G} \alpha 12 / 13$ proteins. Hence, a considerable challenge is the identification of anticancer drugs targeting G $\alpha 12 / 13$, PARs, LPA and SIP receptors.

\section{Lysophosphatidic Acid (LPA) Receptors in Tumor Biology}

The phospholipid LPA signals via no fewer than six receptors (LPA1-LPA6) belonging to the GPCR family. LPA1-LPA3 (also known as EDG2, EDG4, and EDG7, respectively) are expressed by endothelial differentiation genes [17]. LPA4 (also known as GPR23/P2y9), LPA5 (GPR92), and LPA6 (GPR87) are included within the purinergic family of GPCRs [50-52]. Inducing LPA and/or an aberrant expression of its receptors may lead to cancer initiation and progression [53,54]. This has been demonstrated in breast cancer [55] and ovarian cancer [56], where LPA acts via activation of the Rho-dependent transduction pathway to elicit migration and tumor formation. In addition to the manipulation of LPA activity via cognate receptors, novel and selective agonists and antagonists might 
be employed therapeutically through understanding the differences between LPA1-3 receptors, since LPA biosynthesis is considered a feasible target for therapeutics [57].

\section{Chemokine Receptors}

Cancer cells that metastasize preferentially to specific organs via the blood and lymphatic vessels present a great challenge in cancer eradication. One family of GPCRs that is closely linked to tumor metastasis is the chemokine receptors. Chemokines enhance the motility and survival of cancer cells in the vicinity and milieu of a tumor following their local release in either an autocrine or paracrine fashion into the microenvironment of tumor-surrounding regions [58]. Among these are chemokines that are involved in metastatic cancer cell homing [59] as well as cancer cell growth and survival [60], such as chemokine receptors CCR7 and CCR10. Local chemokine generation in the tumor milieu may recruit macrophages and leukocytes, which can then induce the release of matrix metalloproteases (MMPs) promoting tumor cell survival, growth, and invasion as well as improving the cytokine-rich microenvironment. CXCR4 is a well-documented chemokine receptor driving cancer metastasis. Moreover, cells in the most frequent sites of metastasis, including the lungs, bone marrow, lymph nodes, and liver, express the chemokine ligand CXCL12/SDF-1 [61]. Tumor cells frequently express high levels of CXCR4, facilitating cell growth, survival, and migratory capability. For example, while CXCR4 is not found in normal breast tissues, it is rather overexpressed in breast cancer cells [62] and a marked inhibition of breast cancer metastatic spread is achieved by inhibiting CXCR4 [58,62,63]. However, treatment with CXCR4 inhibitors requires caution, since CXCR4 inhibition induces progenitor/stem cell mobilization from the bone marrow. Hypoxia-inducible factor-1 (HIF-1 $\alpha$ ), which is activated by hypoxia, increases CXCR4 transcription [64]. In highly aggressive basal-like breast cancer cells, CXCR4 may also couple to $\mathrm{G} \alpha 12 / 13$ when $\mathrm{G} \alpha 13$ protein is highly upregulated, and consequently drives spread via lymphatic vessels and site-specific metastasis in a G $\alpha 12 / 13-R h o A-d e p e n d e n t$ manner [65]. This molecular machinery is mediated similarly via PARs and LPA, all of which may serve as possible targets for metastasis prevention and treatment.

\section{Wnt Signaling}

Wnt proteins were first identified in Drosophila, from which their name was coined. They are critically involved in controlling both normal development and tissue homeostasis, as well as pathological processes such as cancer. Intensive efforts have been made to unravel the Wnt (Wingless ad INT-1) signaling pathway. Frizzled (Fz) receptors are a subgroup of GPCRs that play a pivotal role in development, tissue homeostasis, and cancer, serving as receptors for Wnts. Wnt signaling stabilizes $\beta$-catenin through Fz and the low-density lipoprotein-related protein 6 (LRP6) receptor complex that antagonizes the $\beta$-catenin "destruction complex". The canonical Wnt pathway refers to the activation of the highly conserved Wnt/ $\beta$-catenin signaling pathway, involving the stabilization of $\beta$-catenin via Wnt binding to Fz cell surface receptors and LRP5 / 6 co-receptors. In the absence of Wnt, the key effector of this pathway, $\beta$-catenin, is continuously degraded by the "degradation complex". This complex is comprised of Axin, adenomatis polyposis coli (APC), glycogen synthase kinase $3 \beta$ $(\mathrm{GSK} 3 \beta)$, casein kinase $1 \alpha(\mathrm{CK} 1 \alpha)$, and the $\mathrm{E} 3$ ubiquitin ligase subunit $\beta-\operatorname{TrCP} 1$. Axin provides a scaffolding site for GSK3 $\beta$ to phosphorylate the $N$-terminal portion of $\beta$-catenin (after priming by $\mathrm{CK} 1 \alpha)$, thereby generating a phosphorylated form of $\beta$-catenin that is recognized by the ubiquitin ligase adaptor $\beta$-TrCP $[66,67]$. Wnt stimulation dismantles the degradation complex, leading to the accumulation of unphosphorylated $\beta$-catenin. Once $\beta$-catenin is stabilized, it is translocated to the cell nucleus. There it alters the activity of the lymphoid enhancer factor (Lef)/T cell factor (Tcf) family members. The Lef/Tcf family belongs to HMG-box transcription factors and acts as a transcriptional switch, recruiting various chromatin modifiers and remodelers to Lef/Tcf target genes, inducing expression of an array of genes downstream (Scheme 1; $[67,68]$ ). A wide range of cancers exhibit hyperactive stabilized $\beta$-catenin, either because of oncogenic mutations in its $\mathrm{N}$-terminal phosphorylation site or through mutational inactivation of APC or Axin, its negative 
regulators $[68,69]$. Activated $\beta$-catenin can be oncogenic, driving the onset of a wide spectrum of carcinomas. Noncanonical Wnt signaling does not involve $\beta$-catenin/Tcf activity and does not utilize the LRP5/ 6 co-receptor. For example, Wnt5a/b are prototypes of this Wnt pathway [70]. In vertebrates, noncanonical Wnt signaling is involved in planar cell polarity (PCP), dorsoventral patterning, tissue regeneration, convergent extension movements, and tumorigenesis. Throughout these processes, alternative Wnt signaling induces the small G protein Rho. Rho activates Rho-associated kinase (ROCK), which is one of the major regulators of the cytoskeleton and, in-general, this noncanonical signaling antagonizes canonical $\mathrm{Wnt} / \beta$-catenin signaling. Fz receptors transduce both $\mathrm{Wnt} / \beta$-catenin and noncanonical Wnt signaling. An interesting yet unresolved aspect of $\mathrm{Fz}$ is the involvement of $\mathrm{G}$ proteins. While $G \alpha$ proteins have been shown to alter Wnt signaling in some studies [71-73], other research has failed to identify $\mathrm{G} \alpha$ proteins as essential components of Wnt/ $\beta$-catenin signaling [74,75]. Thus, the involvement of $\mathrm{G}$ proteins in Wnt signaling pathways is yet an open, controversial issue.

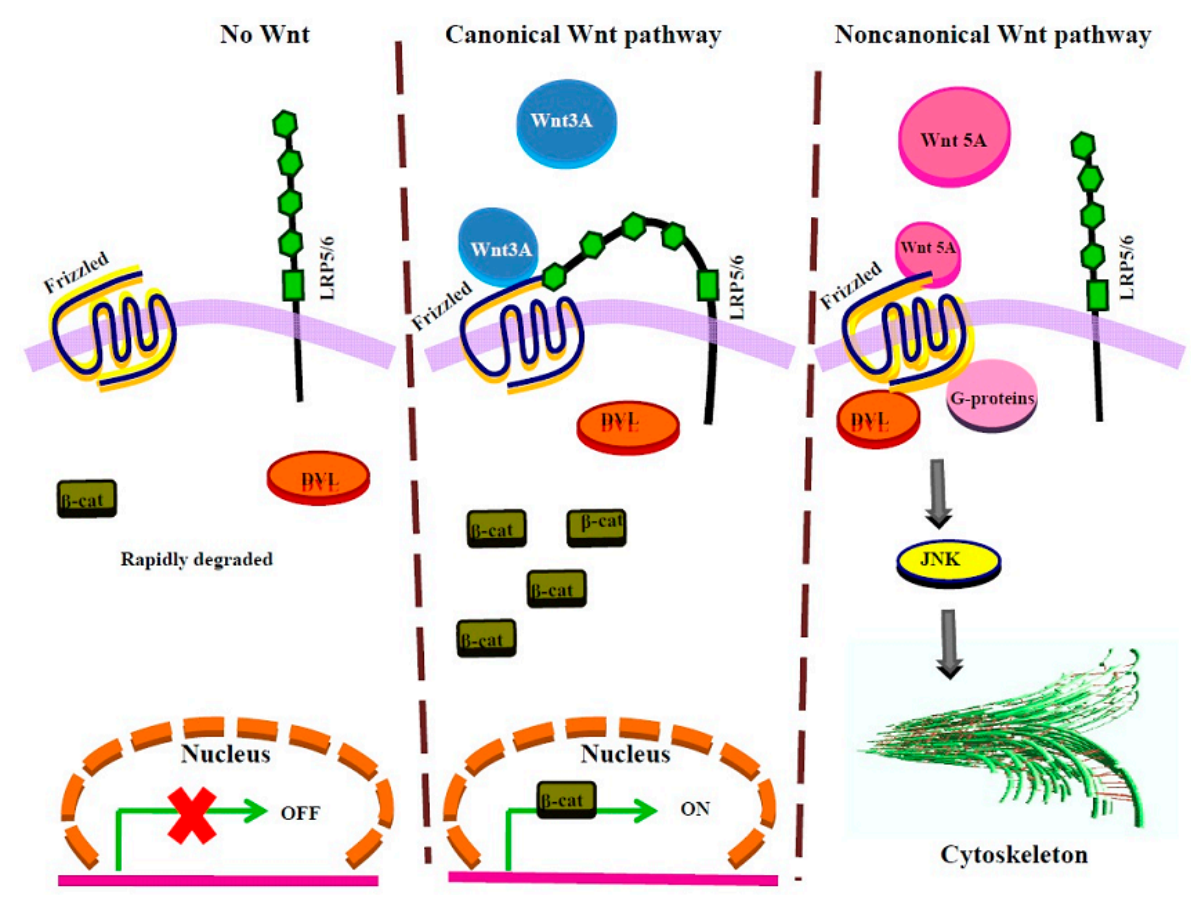

Scheme 1. Illustration of Wnt / $\beta$-catenin canonical and noncanonical pathways. In the presence of a Wnt ligand (e.g., Wnt 3A), Frizzled receptor (Fz) co-associates with LRP5/6, leading to stabilization of $\beta$-catenin. In contrast, in the absence of a Wnt ligand, $\beta$-catenin is rapidly degraded via the proteasomal compartment. Stabilized $\beta$-catenin enters the nuclei and functions as a co-transcription factor, inducing a spectrum of gene signature downstream. Noncanonical Wnt signaling (e.g., Wnt 5a) is mediated via Fz affecting, among others, activation of JNK and the cytoskeleton. Rred cross: Inhibition of signal cascade.

\section{GPCR Regulation of Hippo Signaling Pathway}

The Hippo-YAP/TAZ pathway has emerged as a major conserved path that integrates diverse stimuli in a broad range of functions, including control of cell growth and organ size as well as mechanical and cytoskeletal proteins, apico-basolateral polarity, and cell adhesion [76,77]. Dysregulation of the Hippo signaling pathway leads to cancer development. This dysregulation enables two central downstream effectors of Hippo signaling, Yes-associated protein (YAP) and its homolog protein TAZ, to translocate to the cell nuclei and serve as transcription factors that are considered major components involved in cancer (Scheme 2). As a result, research has been aimed at the development of pharmacological inhibitors to both YAP and TAZ, which serve as potent tumor drug targets. The search for physiological activators of YAP/TAZ led to the finding that GPCRs are actually 
powerful inducers of the YAP oncogenic pathway [78-81]. The tumor-suppressing Hippo pathway plays a major role in inhibiting YAP/TAZ nuclear localization and transcriptional activity, and the oncogenic YAP path is initiated upon abrogation of the Hippo path. Once the Hippo enzymatic cascade of events is inhibited, YAP/TAZ are dislodged from their cytoplasmic anchorage site and translocate to cell nuclei. In the nuclei, they serve as transcription co-activators and stimulate downstream target genes, consequently inducing oncogenicity through binding to TEAD family transcription factors.

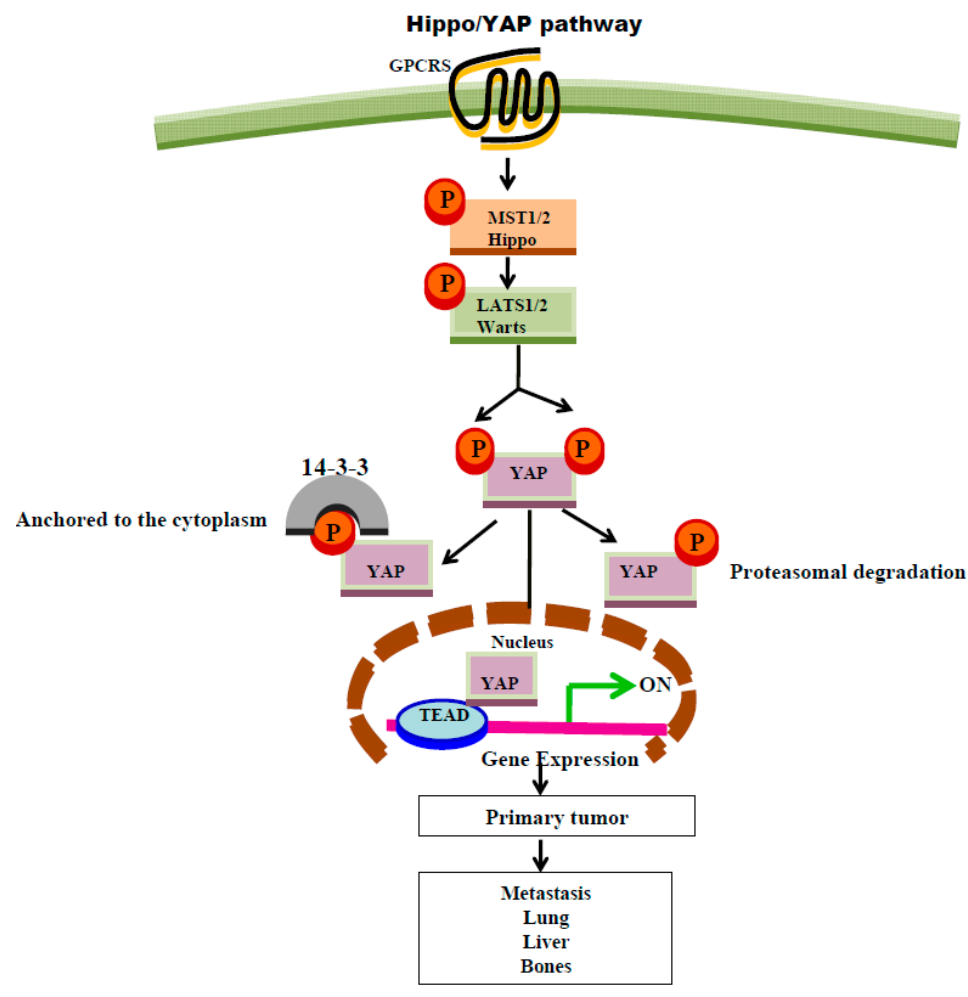

Scheme 2. The Hippo/YAP pathway is physiologically initiated via GPCRs. The Hippo pathway takes place following the phosphorylation of Ltats1/2 by Mst1/2 which leads to the phosphorylation of YAP and its anchoring localization in the cytoplasmic compartment. YAP is activated by inhibition of the Hippo pathway via the de-phosphorylation of YAP, resulting in YAP nuclear localization and its function as a co-transcription factor.

The Mst1/2-Lats1/2 kinase cascade of the Hippo pathway inhibits YAP/TAZ through direct phosphorylation, leading to cytoplasmic retention via the binding of 14-3-3, which further promotes $\beta$-TrCP-mediated YAP/TAZ ubiquitination and degradation. GPCRs that are involved in cell proliferation are in fact capable of stimulating transcriptional activity of the co-activator YAP $[76,80,82-84]$. It has been shown that GPCRs inhibit the activity of LATS via G $\alpha 12 / 13$, thus releasing YAP from LATS-dependent inhibition [80]. Studies from the Gutkind lab [85] have demonstrated that oncogenic mutations in G $\alpha$ q lead to the activation of YAP by a mechano-sensing pathway as well as actin polymerization and not by intervention in the Hippo-suppressing pathway. In addition, recent studies from the Guan lab [86] have described YAP/TAZ as bona fide downstream effectors of the noncanonical Wnt signaling pathway. It was proposed that Wnt5a/b and Wnt3a induce YAP/TAZ activation independent of canonical Wnt/ $\beta$-catenin signaling, and instead via the noncanonical Wnt-YAP/TAZ signaling axis, consisting of Wnt-FZD/ROR G $\alpha 12 / 13-R h o$ GTPases-Lats1/2, to promote stimulation of oncogenic YAP/TAZ- and TEAD-mediated gene transcription.

The regulatory mechanisms controlling YAP and TAZ activity appear to vary between tissues. Based on the fact that induced transcriptional activities of YAP/TAZ are centrally involved in cancer, 
attenuation of YAP and/or TAZ is a rather logical approach for the treatment and prevention of a wide array of malignancies. One approach could be reducing YAP dosage by shRNA depletion. Screens for shRNA-induced lethality in a large panel of human cancer cell lines showed that tumor cell lines activated for WNT signaling are specifically sensitive to the knock-down of YAP [87]. Thus, Rosenbluh et al. [87], underscore the concept that YAP inhibition does not necessarily correlate with levels of YAP activity, and may involve important TEAD-independent interactions mediated via YAP that may be critical for some types of cancer cells.

\section{Protease-Activated Receptors, PARs, and Cancer}

Proteinases and their inhibitors [88] account for over $2 \%$ of human genes. While proteases act by both mechanisms of nonreceptor- and receptor-mediated functions, the fact that they represent a significant percentage of the genome indicates their importance in regulating diverse tissue functions. Cell signaling may be controlled also via digestion of a wide spectrum of zymogens such as kininogens, chemokines, prohormones, and growth factor receptors, for example insulin receptors as well as cytokine precursors. It has also been known for over 40 years that the proteolytic enzymes thrombin and trypsin can induce cell proliferation through cell surface receptor activation, much like traditional growth factors such as epidermal growth factor and insulin [89-92], although the mechanistic details were not understood until sometime later. After an exhaustive search for a receptor that mediates functional responses of the main protease in the coagulation cascade, thrombin, yielded a "thrombin receptor", which acts to induce platelet aggregation as well as cultured cell proliferation. This receptor was called protease-activated receptor, or PAR $[93,94]$. PARs form a subfamily within the larger GPCRs of rhodopsin-like class A GPCRs, and include four members: $\mathrm{PAR}_{1}, \mathrm{PAR}_{2}, \mathrm{PAR}_{3}$, and $\mathrm{PAR}_{4}$ [95]. $\mathrm{PAR}_{1}$, the first and prototype member of the family, mediates the response to thrombin signaling in most cell types, and was thus designated as a "thrombin receptor" [94]. While $\mathrm{PAR}_{3}$ and $\mathrm{PAR}_{4}$ provide a "back-up" system to PAR $_{1}$ [96-98], PAR $_{2}$ is not considered as a thrombin receptor" but is rather activated via a trypsin serine-protease and also by proteases that present upstream to thrombin [99]. PARs are activated via enzymatic digestion of the $\mathrm{N}$-terminal extracellular portion, which gives rise to newly exposed ligands that act through intramolecular binding to extracellular loop number two for signal transmission [100]. Once activated, conformational changes transmitted via the transmembrane TM domains to the cytoplasmic tails enable the binding association with $\alpha$ subunits of $G$ proteins localized within the membrane, inside the cell compartment [101].

\section{Novel Signaling of PARs Endowing Critical PH-Domain Binding Motifs}

Although a growing number of roles for $\mathrm{PAR}_{1 \& 2}$ in oncogenesis have been identified, the basic signaling machinery has not yet been elucidated. Signal-associating motifs in PAR R\&2 $_{2}$ C-tails have been shown to be essential for breast cancer development [102] through binding of signal proteins that possess a pleckstrin-homology (PH)-domain. These include Akt/PKB-PH domain as well as Etk/Bmx and $\mathrm{Vav}_{3}$, all of which can potently associate with both $\mathrm{PAR}_{1}$ and $\mathrm{PAR}_{2}$. The association takes place in a hierarchical manner, whereby priority is attributed to Etk/Bmx. A point mutation in H349APAR 2 , but not in R352A, potently inhibits PH-protein binding and is sufficient to markedly eliminate $\mathrm{PAR}_{2}$-induced breast tumor growth in vivo and placental extravillous trophoblast (EVT) invasion in vitro. Along this line, the $\mathrm{PAR}_{1}$ mutant $h$ Par1-7A, which is incapable of associating with the $\mathrm{PH}$ domain, markedly inhibits mammary tumor development and EVT invasion, demonstrating the physiological significance and importance of these novel $\mathrm{PAR}_{1}$ and $\mathrm{PAR}_{2} \mathrm{PH}$ domain binding motifs in both pathological and normal invasion processes. $\mathrm{PH}$ domains that are present in diverse signal transducing proteins are highly preserved motifs. They function as versatile modules in protein-protein interactions, inducing a multitude of physiological events [103,104]. These associating motifs are required for both tumor development and physiological placental EVT-uterus interactions. In spite of the fact that primary sequence identity between $\mathrm{PH}$ domains is limited, striking similarity is found in their tertiary structures. 
Interestingly, the binding motifs in PARs [102] are either lipid-independent and mediated via protein-protein association, as demonstrated for PH-Etk/Bmx, or lipid-dependent, as is the case of Akt-PH association. One possible explanation is that membrane targeting is mediated via palmitoylation of a cysteine residue in the $\mathrm{PAR}_{1 \& 2} \mathrm{C}$-tail. The previously identified, conserved eighth helix (H8) found in rhodopsin is located within the C-tail of $\mathrm{PAR}_{1}$ and $\mathrm{PAR}_{2}$, as in other receptors that belong to Class A. Specifically, the $\mathrm{PAR}_{1} \mathrm{PH}$ domain binding site is found within the $\mathrm{H} 8$ loop. Likewise, palmitoylation of $\mathrm{PAR}_{2}$ is required for post-translational modification and is necessary for potent cell surface expression and desensitization of $\mathrm{PAR}_{2}$.

In general, regardless of whether binding occurs via lipids or directly through protein-protein interactions, $\mathrm{PH}$ motifs that serve as pivotal binding modules demonstrate that interactions between separate motifs in a signal protein support transmission of a biochemical signal and also ensure a robust response to developmental cues, with sufficient specificity at precisely the right time to protect against premature and disastrous induction of a cell fate alteration. Cell surface receptors that play a central role in cancer biology, for example PARs, act to effectively relay cell signaling by recruiting PH domain signal proteins. PARs may also activate integrins, and vice versa [105]. Formation of the FAK-PH-Etk/Bmx complex, as well as FAK-PH-Rgnef (e.g., binding via PH domain), may initiate signaling in an "inside-out" manner that consequently will affect the extracellular portion of integrins and "activate" them. Once activated, integrins can associate with PARs ([104], see Scheme 3), which then will transmit signaling in an "outside-in" fashion and associate with PH-signal proteins.

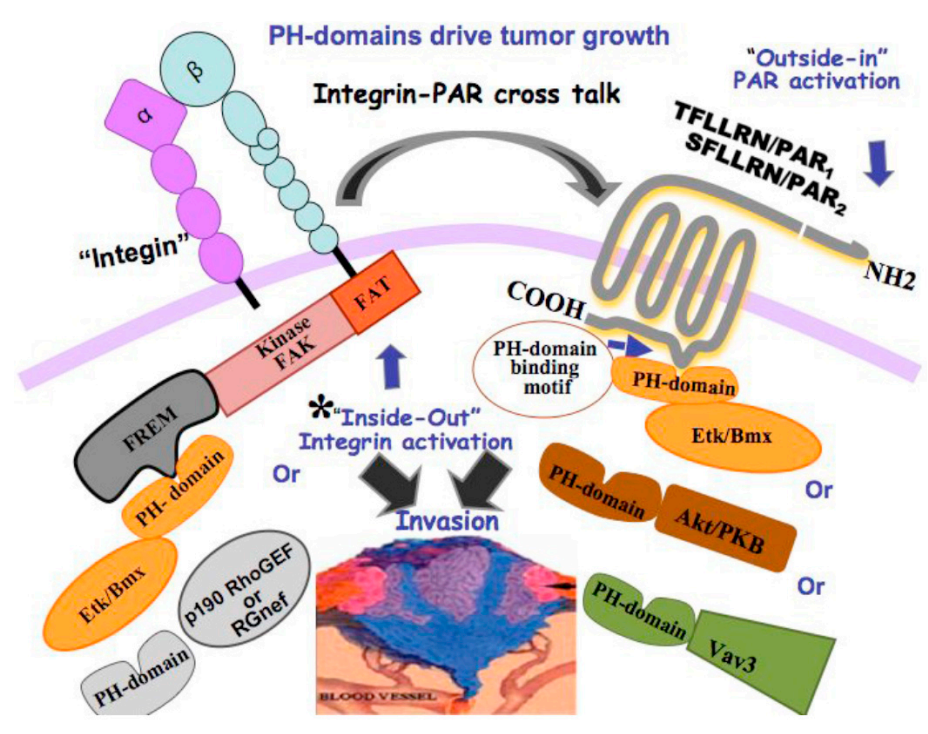

Scheme 3. $\mathrm{PH}$ domains power tumor growth. The activation of $\mathrm{PAR}_{1 \& 2}$ results in binding of $\mathrm{PH}$ signal proteins. These association motifs are essential for tumor development. The "inside-out" mode of integrin activation via either PH-Etk/Bmx-FERM/FAK or PH-Rgnef-FAK can induce interactions with PARs through all stages of cancer development.

\section{Concluding Remarks and Future Directions}

GPCRs are known to activate different signaling pathways initiated by ligand binding (see Table 1 summarizing driver GPCR signaling in cancer). The prospect of biased agonism conferring selectivity of signaling via the binding of several ligands to the same receptor offers advantages in clinical settings. It is desired to help design drugs with fewer unfavorable side effects, specifically in designing a biased ligand that will have a weak activity under one pathway condition but a much stronger activity in another. While hypothetically all GPCRs should demonstrate biased signaling, until now several were found to have this property. It is still not understood how a variety of stabilized conformations of a given receptor give rise to different signaling pathways. This challenging mechanism is in its early phase and needs to be further explored. It remains to be conclusively determined whether changes in 
the receptor conformation are indeed the ground basis for biased agonism signaling. Among other approaches, for example, is the identification of new binding motifs within GPCR C-tails that may allow for the design of selective potent drugs. Such therapeutic medicaments are expected to inhibit diverse signaling pathways initiated by a signaling partner that harbors a specific "signal-motif" for association with GPCRs and initiation of a signaling cascade. For example, the "PH domain binding motifs" within PARs are effectively capable of associating with several PH signal-possessing proteins (e.g., Etk/Bmx, Akt and Vav). There is a plan to identify such PH-binding motifs within the spectrum of GPCRs for future effective drug design.

Table 1. Cancer GPCRs and signaling pathways. Summary of cancer driver GPCRs and their signaling. As such, examples of GPCRs which are implicated in human cancer are listed. Lysophosphatidic acid receptors 1-6 (LPA1-6), protease-activated receptors $\left(\mathrm{PAR}_{1 \& 2}\right)$, Yes-associated protein (YAP), Frizzled receptors $(\mathrm{Fz})$, parathyroid receptor1 (PTHR1), endothelin receptors $\mathrm{A}$ and $\mathrm{B}\left(\mathrm{ET}_{\mathrm{A}} \mathrm{R}\right.$ and $\left.\mathrm{ET}_{\mathrm{B}} \mathrm{R}\right)$, endothelin1-3 (ET1-3), prostaglandin receptors (PE2, PE4), prostaglandin (PGE2), bradykinin receptor type 1 and 2 (B1R, B2R), sphingosine-phosphate receptor 1 (S1PR1).

\begin{tabular}{|c|c|c|}
\hline Receptor & Ligand & Pathways \\
\hline $\begin{array}{l}\text { Lysophosphatidic acid } \\
\text { Receptors (LPA1-6) }\end{array}$ & Lysophosphatidic acid & $\begin{array}{l}\text { Rho-dependent pathway }[37,106] \\
\beta \text {-Catenin stabilization }[107,108] \\
\text { Kruppel-like factor } 5[109]\end{array}$ \\
\hline $\begin{array}{l}\text { Protease activated receptors } \\
\left(\mathrm{PAR}_{1 \& 2)}\right. \\
\text { LPA }\end{array}$ & $\begin{array}{l}\text { Thrombin, Trypsin, respectively, or } \\
\text { TFLLRN (G12/13, PAR1) or SLIGKV } \\
\text { (G12/13, PAR2) [79] } \\
\text { Lysophosphatidic acid (G } \alpha \mathrm{q})[80]\end{array}$ & $\begin{array}{l}\text { Hippo/YAP pathways via activation of } \\
\text { G } \alpha 12 / 13 \text {-coupled receptors or G } \alpha q \text {. Inhibition } \\
\text { of Hippo pathway (via the inhibition of } \\
\text { Lats1/2 kinases ) results in activation of YAP } \\
\text { co-transcriptional activity [110] }\end{array}$ \\
\hline $\begin{array}{l}\text { Frizzled }(\mathrm{Fz}) \text { PAR1 } \\
\text { Parathyroid receptor1 } \\
\text { (PTHR1) }\end{array}$ & $\begin{array}{l}\text { Wnt 3A (canonical pathway) } \\
\text { Thrombin or TFLLRN [111,112] } \\
\text { PTH [113] }\end{array}$ & $\begin{array}{l}\text { Canonical Wnt signaling stabilization of } \\
\beta \text {-catenin }[66,114] \text { and its transcription activity }\end{array}$ \\
\hline Chemokine receptor (CXCR4) & CXCL12, SDF-1 & $\begin{array}{l}\text { PI3K, Akt, Src PIP2, IP3, Ras, Raf, ERK1/2, } \\
\text { PLC, JNK [115] }\end{array}$ \\
\hline PAR1 and PAR2 & $\begin{array}{l}\text { Thrombin or TFLLRN (PAR1) } \\
\text { Trypsin or SLIGKV (PAR2) }\end{array}$ & $\begin{array}{l}\text { PH domain signal partners such as } \\
\text { Etk/Bmx or Akt [102] } \\
\text { G } \alpha 12 / 13 \text {, Rho [24] }\end{array}$ \\
\hline $\begin{array}{l}\text { Endothelin receptors } \\
\text { (ETAR and ETBR) }\end{array}$ & $\begin{array}{l}\text { endothelin-1-3 } \\
\text { (ET-1, ET-2, ET-3) }\end{array}$ & $\begin{array}{l}\text { C-Src/cross talk with EGFR } \\
\beta \text {-arrestin - } 1 \text { or-2 PDZRhoGEF and Rho A, C } \\
\beta \text {-catenin stabilization }[7,21,116]\end{array}$ \\
\hline $\begin{array}{l}\text { Prostaglandin receptors } \\
\text { (PE2, PE4) }\end{array}$ & PGE2 & $\begin{array}{l}\text { Cyclooxygenase (COX-2)pathway P13K } \\
\text { (coupling to Gs) [117-119] }\end{array}$ \\
\hline $\begin{array}{l}\text { Bradykinin Receptor Type } 1 \text { and } 2 \\
\text { (B1R, B2R) }\end{array}$ & Kinins & G $\propto \mathrm{q}$ and Cross talk with EGFR Ras, Raf, ERK \\
\hline $\begin{array}{l}\text { Sphingosine1-phosphate } \\
\text { receptor1 (S1PR1) }\end{array}$ & S1P & $\begin{array}{l}\text { Ras-ERK, PI3K-Akt-Rac, Rho, STAT3 } \\
\text { (coupling to G } \alpha \mathrm{i} \text { ) }[120,121]\end{array}$ \\
\hline
\end{tabular}

Acknowledgments: The studies are supported by grants from the Israel Science Foundation (ISF) and Monsa foundation (RB-S). The authors thank Shifra Fraifeld, a medical writer at the Hadassah-Hebrew University Medical Center, for her editorial assistance during manuscript preparation.

Conflicts of Interest: The authors declare no conflict of interest.

\section{References}

1. Wisler, J.W.; Xiao, K.; Thomsen, A.R.; Lefkowitz, R.J. Recent developments in biased agonism. Curr. Opin. Cell Biol. 2014, 27, 18-24. [CrossRef] [PubMed]

2. Kenakin, T. The potential for selective pharmacological therapies through biased receptor signaling. BMC Pharmacol. Toxicol. 2012, 13, 3. [CrossRef] [PubMed]

3. Hollenberg, M.D.; Mihara, K.; Polley, D.; Suen, J.Y.; Han, A.; Fairlie, D.P.; Ramachandran, R. Biased signalling and proteinase-activated receptors (PARs): Targeting inflammatory disease. Br. J. Pharmacol. 2014, 171, 1180-1194. [CrossRef] [PubMed]

4. Feigin, M.E. Harnessing the genome for characterization of G-protein coupled receptors in cancer pathogenesis. FEBS J. 2013, 280, 4729-4738. [CrossRef] [PubMed] 
5. Whalen, E.J.; Rajagopal, S.; Lefkowitz, R.J. Therapeutic potential of $\beta$-arrestin- and G protein-biased agonists. Trends Mol. Med. 2011, 17, 126-139. [CrossRef] [PubMed]

6. Cianfrocca, R.; Tocci, P.; Semprucci, E.; Spinella, F.; di Castro, V.; Bagnato, A.; Rosanò, L. $\beta$-Arrestin 1 is required for endothelin-1-induced NF-KB activation in ovarian cancer cells. Life Sci. 2014, 118, 179-184. [CrossRef] [PubMed]

7. Rosanò, L.; Cianfrocca, R.; Tocci, P.; Spinella, F.; di Castro, V.; Spadaro, F.; Salvati, E.; Biroccio, A.M.; Natali, P.G.; Bagnato, A. $\beta$-arrestin-1 is a nuclear transcriptional regulator of endothelin-1-induced $\beta$-catenin signaling. Oncogene 2013, 32, 5066-5077. [CrossRef] [PubMed]

8. Lappano, R.; Maggiolini, M. G protein-coupled receptors: Novel targets for drugdiscovery in cancer. Nat. Rev. Drug Discov. 2011, 10, 47-60. [CrossRef] [PubMed]

9. Dorsam, R.T.; Gutkind, J.S. G-protein-coupled receptors and cancer. Nat. Rev. Cancer. 2007, 7, 79-94. [CrossRef] [PubMed]

10. Xu, N.; Bradley, L.; Ambdukar, I.; Gutkind, J.S. A mutant $\alpha$ subunit of G12 potentiates the eicosanoid pathway and is highly oncogenic in NIH 3T3 cells. Proc. Natl. Acad. Sci. USA 1993, 90, 6741-6745. [CrossRef] [PubMed]

11. Jiang, H.; Wu, D.; Simon, M.I. The transforming activity of activated G $\alpha$ 12. FEBS Lett. 1993, 330, 319-322. [CrossRef]

12. Voyno-Yasenetskaya, T.A.; Pace, A.M.; Bourne, H.R. Mutant $\alpha$ subunits of G12 and G13 proteins induce neoplastic transformation of Rat-1 fibroblasts. Oncogene 1994, 9, 2559-2565. [PubMed]

13. Dhanasekaran, N.; Prasad, M.V.; Wadsworth, S.J.; Dermott, J.M.; van Rossum, G. Protein kinase C-dependent and -independent activation of $\mathrm{Na}^{+} / \mathrm{H}^{+}$exchanger by $\mathrm{G} \alpha 12$ class of $\mathrm{G}$ proteins. J. Biol. Chem. 1994, 269, 11802-11806. [PubMed]

14. Hooley, R.; Yu, C.Y.; Symons, M.; Barber, D.L. G $\alpha 13$ stimulates $\mathrm{Na}^{+}-\mathrm{H}^{+}$exchange through distinct Cdc42-dependent and RhoA-dependent pathways. J. Biol. Chem. 1996, 271, 6152-6158. [PubMed]

15. Offermanns, S.; Mancino, V.; Revel, J.P.; Simon, M.I. Vascular system defects and impaired cell chemokinesis as a result of G $\alpha 13$ deficiency. Science 1997, 275, 533-536. [CrossRef] [PubMed]

16. Tigyi, G. Aiming drug discovery at lysophosphatidic acid targets. Br. J. Pharmacol. 2010, 161, $241-247$. [CrossRef] [PubMed]

17. Contos, J.J.; Ishii, I.; Chun, J. Lysophosphatidic acid receptors. Mol. Pharmacol. 2000, 58, 1188-1196. [PubMed]

18. Willier, S.; Butt, E.; Grunewald, T.G. Lysophosphatidic acid (LPA) signalling in cell migration and cancer invasion: A focused review and analysis of LPA receptor gene expression on the basis of more than 1700 cancer microarrays. Biol. Cell 2013, 105, 317-333. [CrossRef] [PubMed]

19. Seo, H.; Kim, M.; Choi, Y.; Lee, C.K.; Ka, H. Analysis of lysophosphatidic acid (LPA) receptor and LPA-induced endometrial prostaglandin-endoperoxide synthase 2 expression in the porcine uterus. Endocrinology 2008, 149, 6166-6167. [CrossRef] [PubMed]

20. Wang, P.; Wu, X.; Chen, W.; Liu, J.; Wang, X. The lysophosphatidic acid (LPA) receptors their expression and significance in epithelial ovarian neoplasms. Gynecol. Oncol. 2007, 104, 714-720. [CrossRef] [PubMed]

21. Rosanò, L.; Spinella, F.; Bagnato, A. Endothelin 1 in cancer: Biological implications and therapeutic opportunities. Nat. Rev. Cancer. 2013, 13, 637-651. [CrossRef] [PubMed]

22. Venkatakrishnan, A.J.; Deupi, X.; Lebon, G.; Tate, C.G.; Schertler, G.F.; Babu, M.M. Molecular signatures of G-protein-coupled receptors. Nature 2013, 494, 185-194. [CrossRef] [PubMed]

23. Bodor, E.T.; Offermanns, S. Nicotinic acid: An old drug with a promising future. Br. J. Pharmacol. 2008, 153, S68-S75. [CrossRef] [PubMed]

24. Soto, A.G.; Smith, T.H.; Chen, B.; Bhattacharya, S.; Cordova, I.C.; Kenakin, T.; Vaidehi, N.; Trejo, J. N-linked glycosylation of protease-activated receptor-1 at extracellular loop 2 regulates G-protein signaling bias. Proc. Natl. Acad. Sci. USA 2015, 112, E3600-E3608. [CrossRef] [PubMed]

25. Kenakin, T. Functional selectivity and biased receptor signaling. J. Pharmacol. Exp. Ther. 2011, 336, $296-302$. [CrossRef] [PubMed]

26. Gesty-Palmer, D.; Chen, M.; Reiter, E.; Ahn, S.; Nelson, C.D.; Wang, S.; Eckhardt, A.E.; Cowan, C.L.; Spurney, R.F.; Luttrell, L.M.; et al. Distinct $\beta$-arrestin- and G protein-dependent pathways for parathyroid hormone receptor-stimulated ERK1/2 activation. J. Biol. Chem. 2006, 281, 10856-10864. [CrossRef] [PubMed] 
27. Bryja, V.; Gradl, D.; Schambony, A.; Arenas, E.; Schulte, G. B-arrestin is a necessary component of Wnt/ $\beta$-catenin signaling in vitro and in vivo. Proc. Natl. Acad. Sci. USA 2007, 104, 6690-6695. [CrossRef] [PubMed]

28. Rosanò, L.; Cianfrocca, R.; Masi, S.; Spinella, F.; di Castro, V.; Biroccio, A.; Salvati, E.; Nicotra, M.R.; Natali, P.G.; Bagnato, A. B-arrestin links endothelin A receptor to $\beta$-catenin signaling to induce ovarian cancer cell invasion and metastasis. Proc. Natl. Acad. Sci. USA 2009, 106, 2806-2811. [CrossRef] [PubMed]

29. Young, D.; Waitches, G.; Birchmeier, C.; Fasano, O.; Wigler, M. Isolation and characterization of a new cellular oncogene encoding a protein with multiple potential transmembrane domains. Cell 1986, 45, 711-719. [CrossRef]

30. Davenport, A.P.; Alexander, S.P.; Sharman, J.L.; Pawson, A.J.; Benson, H.E.; Monaghan, A.E.; Liew, W.C.; Mpamhanga, C.P.; Bonner, T.I.; Neubig, R.R.; et al. International Union of Basic and Clinical Pharmacology. LXXXVIII. G protein-coupled receptor list: Recommendations for new pairings with cognate ligands. Pharmacol. Rev. 2013, 65, 967-986. [CrossRef] [PubMed]

31. Zohn, I.E.; Klinger, M.; Karp, X.; Kirk, H.; Symons, M.; Chrzanowska-Wodnicka, M.; Der, C.J.; Kay, R.J. G2A is an oncogenic $\mathrm{G}$ protein-coupled receptor. Oncogene 2000, 19, 3866-3877. [CrossRef] [PubMed]

32. Weng, Z.; Fluckiger, A.C.; Nisitani, S.; Wahl, M.I.; Le, L.Q.; Hunter, C.A.; Fernal, A.A.; Le Beau, M.M.; Witte, O.N. A DNA damage and stress inducible G protein-coupled receptor blocks cells in G2/M. Proc. Natl. Acad. Sci. USA 1998, 95, 12334-12339. [CrossRef] [PubMed]

33. Martin, C.B.; Mahon, G.M.; Klinger, M.B.; Kay, R.J.; Symons, M.; Der, C.J.; Whitehead, I.P. The thrombin receptor, PAR-1, causes transformation by activation of Rho-mediated signaling pathways. Oncogene 2001, 20, 1953-1963. [CrossRef] [PubMed]

34. Whitehead, I.; Kirk, H.; Kay, R. Expression cloning of oncogenes by retroviral transfer of cDNA libraries. Mol. Cell. Biol. 1995, 15, 704-710. [CrossRef] [PubMed]

35. Even-Ram, S.; Uziely, B.; Cohen, P.; Grisaru-Granovsky, S.; Maoz, M.; Ginzburg, Y.; Reich, R.; Vlodavsky, I.; Bar-Shavit, R. Thrombin receptor overexpression in malignant and physiological invasion processes. Nat. Med. 1998, 4, 909-914. [CrossRef] [PubMed]

36. Xu, N.; Voyno-Yasenetskaya, T.; Gutkind, J.S. Potent transforming activity of the G13 $\alpha$ subunit defines a novel family of oncogenes. Biochem. Biophys. Res. Commun. 1994, 201, 603-609. [CrossRef] [PubMed]

37. Kawanabe, Y.; Okamoto, Y.; Nozaki, K.; Hashimoto, N.; Miwa, S.; Masaki, T. Molecular mechanism for endothelin-1-induced stress-fiber formation: Analysis of $G$ proteins using a mutant endothelin(A) receptor. Mol. Pharmacol. 2002, 61, 277-284. [CrossRef] [PubMed]

38. Kelly, P.; Casey, P.J.; Meigs, E. Biologic functions of the G12 subfamily of heterotrimeric G proteins: Growth, migration, and metastasis. Biochemistry 2007, 46, 6677-6687. [CrossRef] [PubMed]

39. Lee, S.J.; Yang, J.W.; Cho, I.J.; Kim, W.D.; Cho, M.K.; Lee, C.H.; Kim, S.G. The Gep oncogenes, G $\alpha$ and G $\alpha$, upregulate the transforming growth factor- $\beta 1$ gene. Oncogene 2009, 28, 1230-1240. [CrossRef] [PubMed]

40. Simon, M.I.; Strathmann, M.P.; Gautam, N. Diversity of G proteins in signal transduction. Science 1991, 252, 802-808. [CrossRef] [PubMed]

41. Hepler, J.R.; Gilman, A.G. G proteins. Trends Biochem. Sci. 1992, 17, 383-395. [CrossRef]

42. Conklin, B.R.; Bourne, H.R. Structural elements of $G \alpha$ subunits that interact with $G \beta \gamma$, receptors, and effectors. Cell 1993, 73, 631-641. [CrossRef]

43. Chan, A.M.; Fleming, T.P.; McGovern, E.S.; Chedid, M.; Miki, T.; Aaronson, S.A. Expression cDNA cloning of a transforming gene encoding the wild-type G $\alpha 12$ gene product. Mol. Cell. Biol. 1993, 13, 762-768. [CrossRef] [PubMed]

44. Dhanasekaran, N.; Dermott, J.M. Signaling by the G12 class of G proteins. Cell Signal. 1996, 8, $235-245$. [CrossRef]

45. Goldsmith, Z.G.; Dhanasekaran, D.N. G protein regulation of MAPK networks. Oncogene 2007, 26, 3122-3142. [CrossRef] [PubMed]

46. Kuner, R.; Swiercz, J.M.; Zywietz, A.; Tappe, A.; Offermanns, S. Characterization of the expression of PDZ-RhoGEF, LARG and $\mathrm{G}(\alpha) 12 / \mathrm{G}(\alpha) 13$ proteins in the murine nervous system. Eur. J. Neurosci. 2002, 16, 2333-2340. [CrossRef] [PubMed]

47. Kurose, H. G $\alpha 12$ and G $\alpha 13$ as key regulatory mediator in signal transduction. Life Sci. 2003, 74, $155-161$. [CrossRef] [PubMed] 
48. Fujii, T.; Onohara, N.; Maruyama, Y.; Tanabe, S.; Kobayashi, H.; Fukutomi, M.; Nagamatsu, Y.; Nishihara, N.; Inoue, R.; Sumimoto, H.; et al. G $\alpha 12 / 13$-mediated production of reactive oxygen species is critical for angiotensin receptor-induced NFAT activation in cardiac fibroblasts. J. Biol. Chem. 2005, 280, 23041-23047. [CrossRef] [PubMed]

49. Kumar, R.N.; Shore, S.K.; Dhanasekaran, N. Neoplastic transformation by the Gep oncogene, G $\alpha 12$, involves signaling by STAT3. Oncogene 2006, 25, 899-906. [CrossRef] [PubMed]

50. Noguchi, K.; Ishii, S.; Shimizu, T. Identification of p2y9/GPR23 as a novel G protein-coupled receptor for lysophosphatidic acid, structurally distant from the Edg family. J. Biol. Chem. 2003, 278, 25600-25606. [CrossRef] [PubMed]

51. Lee, C.W.; Rivera, R.; Gardell, S.; Dubin, A.E.; Chun, J. GPR92 as a new G12/13- and Gq-coupled lysophosphatidic acid receptor that increases cAMP, LPA5. J. Biol. Chem. 2006, 281, 23589-23597. [CrossRef] [PubMed]

52. Tabata, K.; Baba, K.; Shiraishi, A.; Ito, M.; Fujita, N. The orphan GPCR GPR87 was deorphanized and shown to be a lysophosphatidic acid receptor. Biochem. Biophys. Res. Commun. 2007, 363, 861-866. [CrossRef] [PubMed]

53. Mills, G.B.; Moolenaar, W.H. The emerging role of lysophosphatidic acid in cancer. Nat. Rev. Cancer 2003, 3, 582-591. [CrossRef] [PubMed]

54. Yang, M.; Zhong, W.W.; Srivastava, N.; Slavin, A.; Yang, J.; Hoey, T.; An, S. G protein-coupled lysophosphatidic acid receptors stimulate proliferation of colon cancer cells through the $\beta$-catenin pathway. Proc. Natl. Acad. Sci. USA 2005, 102, 6027-6032. [CrossRef] [PubMed]

55. Chen, M.; Towers, L.N.; O'Connor, K.L. LPA2 (EDG4) mediates Rho-dependent chemotaxis with lower efficacy than LPA1 (EDG2) in breast carcinoma cells. Am. J. Physiol. Cell Physiol. 2007, 292, C1927-C1933. [CrossRef] [PubMed]

56. Bian, D.; Mahanivong, C.; Yu, J.; Frisch, S.M.; Pan, Z.K.; Ye, R.D.; Huang, S. The G12/13-Rho a signaling pathway contributes to efficient lysophosphatidic acid-stimulated cell migration. Oncogene 2006, 25, 2234-2244. [CrossRef] [PubMed]

57. Aoki, J.; Taira, A.; Takanezawa, Y.; Kishi, Y.; Hama, K.; Kishimoto, T.; Mizuno, K.; Saku, K.; Taguchi, R.; Arai, H. Serum lysophosphatidic acid is produced through diverse phospholipase pathways. J. Biol. Chem. 2002, 277, 48737-48744. [CrossRef] [PubMed]

58. Balkwill, F. Cancer and the chemokine network. Nat. Rev. Cancer 2004, 4, 540-550. [CrossRef] [PubMed]

59. Zlotnik, A.; Burkhardt, A.M.; Homey, B. Homeostatic chemokine receptors and organ-specific metastasis. Nat. Rev. Immunol. 2011, 11, 597-606. [CrossRef] [PubMed]

60. O’Hayre, M.; Salanga, C.L.; Handel, T.M.; Allen, S.J. Chemokines and cancer: Migration, intracellular signalling and intercellular communication in the microenvironment. Biochem. J. 2008, 409, 635-649. [CrossRef] [PubMed]

61. Müller, A.; Homey, B.; Soto, H.; Ge, N.; Catron, D.; Buchanan, M.E.; McClanahan, T.; Murphy, E.; Yuan, W.; Wagner, S.N.; et al. Involvement of chemokine receptors in breast cancer metastasis. Nature 2001, 410, 50-56. [CrossRef] [PubMed]

62. Chambers, A.F.; Groom, A.C.; MacDonald, I.C. Dissemination and growth of cancer cells in metastatic sites. Nat. Rev. Cancer 2002, 2, 563-572. [CrossRef] [PubMed]

63. Burger, J.A.; Kipps, T.J. CXCR4: A key receptor in the crosstalk between tumor cells and their microenvironment. Blood 2006, 107, 1761-1767. [CrossRef] [PubMed]

64. Staller, P.; Sulitkova, J.; Lisztwan, J.; Moch, H.; Oakeley, E.J.; Krek, W. Chemokine receptor CXCR4 down regulated by von Hippel-Lindau tumour suppressor pVHL. Nature 2003, 425, 307-311. [CrossRef] [PubMed]

65. Yagi, H.; Tan, W.; Dillenburg-Pilla, P.; Armando, S.; Amornphimoltham, P.; Simaan, M.; Weigert, R.; Molinolo, A.A.; Bouvier, M.; Gutkind, J.S. A synthetic biology approach reveals a CXCR4-G13-Rho signaling axis driving transendothelial migration of metastatic breast cancer cells. Sci. Signal. 2011, 4, ra60. [CrossRef] [PubMed]

66. Clevers, H. Wnt/ $\beta$-catenin signaling in development and disease. Cell 2006, 127, 469-480. [CrossRef] [PubMed]

67. Nusse, R. Wnt signaling in disease and in development. Cell Res. 2005, 15, 28-32. [CrossRef] [PubMed] 
68. Korinek, V.; Barker, N.; Morin, P.J.; van Wichen, D.; de Weger, R.; Kinzler, K.W.; Vogelstein, B.; Clevers, H. Constitutive transcriptional activation by a $\beta$-catenin-Tcf complex in $\mathrm{APC}^{-/-}$colon carcinoma. Science 1997, 275, 1784-1787. [CrossRef] [PubMed]

69. Valenta, T.; Hausmann, G.; Basler, K. The many faces and functions of $\beta$-catenin. EMBO J. 2012, 31, $2714-2736$. [CrossRef] [PubMed]

70. Van Amerongen, R. Alternative Wnt pathways and receptors. Cold Spring Harb. Perspect. Biol. 2012, 4, a007914. [CrossRef] [PubMed]

71. Katanaev, V.L.; Ponzielli, R.; Sémériva, M.; Tomlinson, A. Trimeric G protein-dependent frizzled signaling in Drosophila. Cell 2005, 120, 111-122. [CrossRef] [PubMed]

72. Liu, T.; DeCostanzo, A.J.; Liu, X.; Wang, Hy.; Hallagan, S.; Moon, R.T.; Malbon, C.C. G protein signaling from activated rat frizzled-1 to the $\beta$ catenin-Lef-Tcf pathway. Science 2001, 292, 1718-1722. [CrossRef] [PubMed]

73. Slusarski, D.C.; Corces, V.G.; Moon, R.T. Interaction of Wnt and a Frizzled homologue triggers G-protein-linked phosphatidylinositol signalling. Nature 1997, 390, 410-413. [PubMed]

74. Major, M.B.; Roberts, B.S.; Berndt, J.D.; Marine, S.; Anastas, J.; Chung, N.; Ferrer, M.; Yi, X.; Stoick-Cooper, C.L.; von Haller, P.D.; et al. New regulators of Wnt/ $\beta$-catenin signaling revealed by integrative molecular screening. Sci. Signal. 2008, 1, ra12. [CrossRef] [PubMed]

75. Regard, J.B.; Cherman, N.; Palmer, D.; Kuznetsov, S.A.; Celi, F.S.; Guettier, J.M.; Chen, M.; Bhattacharyya, N.; Wess, J.; Coughlin, S.R.; et al. Wnt/B-catenin signaling is differentially regulated by Ga proteins and contributes to fibrous dysplasia. Proc. Natl. Acad. Sci. USA 2011, 108, 20101-20106. [CrossRef] [PubMed]

76. Miller, E.; Yang, J.; DeRan, M.; Wu, C.; Su, A.I.; Bonamy, G.M.; Liu, J.; Peters, E.C.; Wu, X. Identification of serum-derived sphingosine-1-phosphate as a small molecule regulator of YAP. Chem. Biol. 2012, 19, 955-962. [CrossRef] [PubMed]

77. Mo, J.S.; Yu, F.X.; Gong, R.; Brown, J.H.; and Guan, K.L. Regulation of the Hippo-YAP pathway by protease-activated receptors (PARs). Genes Dev. 2012, 26, 2138-2143. [CrossRef] [PubMed]

78. Yu, F.X.; Zhao, B.; Panupinthu, N.; Jewell, J.L.; Lian, I.; Wang, L.H.; Zhao, J.; Yuan, H.; Tumaneng, K.; Li, H.; et al. Regulation of the Hippo-YAP pathway by G-protein-coupled receptor signaling. Cell 2012, 150, 780-791. [CrossRef] [PubMed]

79. Yu, F.X.; Luo, J.; Mo, J.S.; Liu, G.; Kim, Y.C.; Meng, Z.; Zhao, L.; Peyman, G.; Ouyang, H.; Jiang, W.; et al. Mutant Gq/11 promote uveal melanoma tumorigenesis by activating YAP. Cancer Cell 2014, 25, 822-830. [CrossRef] [PubMed]

80. Pan, D. The hippo signaling pathway in development and cancer. Dev. Cell 2010, 19, 491-505. [CrossRef] [PubMed]

81. Yu, F.X.; Zhang, Y.; Park, H.W.; Jewell, J.L.; Chen, Q.; Deng, Y.; Pan, D.; Taylor, S.S.; Lai, Z.C.; Guan, K.L. Protein kinase A activates the Hippo pathway to modulate cell proliferation and differentiation. Genes Dev. 2013, 27, 1223-1232. [CrossRef] [PubMed]

82. Ramos, A.; Camargo, F.D. The Hippo signaling pathway and stem cell biology. Trends Cell Biol. 2012, 22, 339-346. [CrossRef] [PubMed]

83. Zhao, B.; Li, L.; Lei, Q.; Guan, K.L. The Hippo-YAP pathway in organ size control and tumorigenesis: An updated version. Genes Dev. 2010, 24, 862-874. [CrossRef] [PubMed]

84. Sudol, M.; Bork, P.; Einbond, A.; Kastury, K.; Druck, T.; Negrini, M.; Huebner, K.; Lehman, D. Characterization of the mammalian YAP (Yes-associated protein) gene and its role in defining a novel protein module, the WW domain. J. Biol. Chem. 1995, 270, 14733-14741. [CrossRef] [PubMed]

85. Feng, X.; Degese, M.S.; Iglesias-Bartolome, R.; Vaque, J.P.; Molinolo, A.A.; Rodrigues, M.; Zaidi, M.R.; Ksander, B.R.; Merlino, G.; Sodhi, A.; et al. Hippo-independent activation of YAP by the GNAQ uveal melanoma oncogene through a trio-regulated rho GTPase signaling circuitry. Cancer Cell 2014, 25, 831-845. [CrossRef] [PubMed]

86. Park, H.W.; Kim, Y.C.; Yu, B.; Moroishi, T.; Mo, J.S.; Plouffe, S.W.; Meng, Z.; Lin, K.C.; Yu, F.X.; Alexander, C.M.; et al. Alternative Wnt signaling activates YAP/TAZ. Cell 2015, 162, 780-789. [CrossRef] [PubMed]

87. Rosenbluh, J.; Nijhawan, D.; Cox, G.; Li, X.; Neal, J.T.; Schafer, E.J.; Zack, T.I.; Wang, X.; Tsherniak, A.; Schinzel, A.C.; et al. $\beta$-Catenin-driven cancers require a YAP1 transcriptional complex for survival and tumorigenesis. Cell 2012, 151, 1457-1473. [CrossRef] [PubMed] 
88. Puente, X.S.; Gutiérrez-Fernández, A.; Ordóñez, G.R.; Hillier, L.W.; López-Otín, C. Comparative genomic analysis of human and chimpanzee proteases. Genomics 2005, 86, 638-647. [CrossRef] [PubMed]

89. Burger, M.M. Proteolytic enzymes initiating cell division and escape from contact inhibition of growth. Nature 1970, 227, 170-171. [CrossRef] [PubMed]

90. Chen, L.B.; Buchanan, J.M. Mitogenic activity of blood components. I. Thrombin and prothrombin. Proc. Natl. Acad. Sci. USA 1975, 72, 131-135. [CrossRef] [PubMed]

91. Carney, D.H.; Cunningham, D.D. Initiation of check cell division by trypsin action at the cell surface. Nature 1977, 268, 602-606. [CrossRef] [PubMed]

92. Carney, D.H.; Cunningham, D.D. Cell surface action of thrombin is sufficient to initiate division of chick cells. Cell 1978, 14, 811-823. [CrossRef]

93. Rasmussen, U.B.; Vouret-Craviari, V.; Jallat, S.; Schlesinger, Y.; Pagès, G.; Pavirani, A.; Lecocq, J.P.; Pouysségur, J.; van Obberghen-Schilling, E. cDNA cloning and expression of a hamster $\alpha$-thrombin receptor coupled to $\mathrm{Ca}^{2+}$ mobilization. FEBS Lett. 1991, 288, 123-128. [CrossRef]

94. Vu, T.K.; Hung, D.T.; Wheaton, V.I.; Coughlin, S.R. Molecular cloning of a functional thrombin receptor reveals a novel proteolytic mechanism of receptor activation. Cell 1991, 64, 1057-1068. [CrossRef]

95. Coughlin, S.R. Protease-activated receptors start a family. Proc. Natl. Acad. Sci. USA 1994, 91, 9200-9202. [CrossRef] [PubMed]

96. Ishihara, H.; Connolly, A.J.; Zeng, D.; Kahn, M.L.; Zheng, Y.W.; Timmons, C.; Tram, T.; Coughlin, S.R. Protease-activated receptor 3 is a second thrombin receptor in humans. Nature 1997, 386, 502-506. [CrossRef] [PubMed]

97. Kahn, M.L.; Zheng, Y.W.; Huang, W.; Bigornia, V.; Zeng, D.; Moff, S.; Farese, R.V.J.; Tam, C.; Coughlin, S.R. A dual thrombin receptor system for platelet activation. Nature 1998, 394, 690-694. [PubMed]

98. Xu, W.F.; Andersen, H.; Whitmore, T.E.; Presnell, S.R.; Yee, D.P.; Ching, A.; Gilbert, T.; Davie, E.W.; Foster, D.C. Cloning and characterization of human protease-activated receptor 4. Proc. Natl. Acad. Sci. USA 1998, 95, 6642-6646. [CrossRef] [PubMed]

99. Nystedt, S.; Emilsson, K.; Wahlestedt, C.; Sundelin, J. Molecular cloning of a potential proteinase activated receptor. Proc. Natl. Acad. Sci. USA 1994, 91, 9208-9210. [CrossRef] [PubMed]

100. Coughlin, S.R. How the protease thrombin talks to cells. Proc. Natl. Acad. Sci. USA 1999, 96, $11023-11027$. [CrossRef] [PubMed]

101. Oldham, W.M.; Hamm, H.E. Heterotrimeric G protein activation by G-protein-coupled receptors. Nat. Rev. Mol. Cell Biol. 2008, 9, 60-71. [CrossRef] [PubMed]

102. Kancharla, A.; Maoz, M.; Jaber, M.; Agranovich, D.; Peretz, T.; Grisaru-Granovsky, S.; Uziely, B.; Bar-Shavit, R. PH motifs in PAR $1 \& 2$ endow breast cancer growth. Nat. Commun. 2015, 6, 8853-8865. [PubMed]

103. Konishi, H.; Kuroda, S.; Kikkawa, U. The pleckstrin homology domain of RAC protein kinase associates with the regulatory domain of protein kinase C zeta. Biochem. Biophys. Res. Commun. 1994, 205, 1770-1775. [CrossRef] [PubMed]

104. Yao, L.; Kawakami, Y.; Kawakami, T. The pleckstrin homology domain of Bruton tyrosine kinase interacts with protein kinase C. Proc. Natl. Acad. Sci. USA 1994, 91, 9175-9179. [CrossRef] [PubMed]

105. Even-Ram, S.C.; Maoz, M.; Pokroy, E.; Reich, R.; Katz, B.Z.; Gutwein, P.; Altevogt, P.; Bar-Shavit, R. Tumor cell invasion is promoted by activation of protease activated receptor- 1 in cooperation with the $\alpha \mathrm{v} \beta 5$ integrin. J. Biol. Chem. 2001, 276, 10952-10962. [CrossRef] [PubMed]

106. Jeong, K.J.; Park, S.Y.; Cho, K.H.; Sohn, J.S.; Lee, J.; Kim, Y.K.; Kang, J.; Park, C.G.; Han, J.W.; Lee, H.Y. The Rho/ROCK pathway for lysophosphatidic acid-induced proteolytic enzyme expression and ovarian cancer cell invasion. Oncogene 2012, 31, 4279-4289. [CrossRef] [PubMed]

107. Sun, Y.; Kim, N.H.; Ji, L.; Kim, S.H.; Lee, J.; Rhee, H.J. Lysophosphatidic acid activates $\beta$-catenin/T cell factor signaling, which contributes to the suppression of apoptosis in H19-7 cells. Mol. Med. Rep. 2013, 8, 1729-1733. [PubMed]

108. Burkhalter, R.J.; Westfall, S.D.; Liu, Y.; Stack, M.S. Lysophosphatidic acid initiates epithelial to mesenchymal transition and induces $\beta$-catenin-mediated transcription in epithelial ovarian carcinoma. J. Biol. Chem. 2015, 290, 22143-22154. [CrossRef] [PubMed]

109. Zhang, H.; Bialkowska, A.; Rusovici, R.; Chanchevalap, S.; Shim, H.; Katz, J.P.; Yang, V.W.; Yun, C.C. Lysophosphatidic acid facilitates proliferation of colon cancer cells via induction of Krüppel-like factor 5. J. Biol. Chem. 2007, 282, 15541-15549. [CrossRef] [PubMed] 
110. Moroishi, T.; Park, H.W.; Qin, B.; Chen, Q.; Meng, Z.; Plouffe, S.W.; Taniguchi, K.; Yu, F.X.; Karin, M.; Pan, D.; et al. A YAP/TAZ-induced feedback mechanism regulates Hippo pathway homeostasis. Genes Dev. 2015, 29, 1271-1284. [CrossRef] [PubMed]

111. Yin, Y.J.; Katz, V.; Salah, Z.; Maoz, M.; Cohen, I.; Uziely, B.; Turm, H.; Grisaru-Granovsky, S.; Suzuki, H.; Bar-Shavit, R. Mammary gland tissue targeted overexpression of human protease-activated receptor 1 reveals a novel link to $\beta$-catenin stabilization. Cancer Res. 2006, 66, 5224-5233. [CrossRef] [PubMed]

112. Turm, H.; Maoz, M.; Katz, V.; Yin, Y.J.; Offermanns, S.; Bar-Shavit, R. Protease-activated receptor-1 (PAR1) acts via a novel $G \alpha 13$-dishevelled axis to stabilize $\beta$-catenin levels. J. Biol. Chem. 2010, 285, 15137-15148. [CrossRef] [PubMed]

113. Romero, G.; Sneddon, W.B.; Yang, Y.; Wheeler, D.; Blair, H.C.; Friedman, P.A. Parathyroid hormone receptor directly interacts with dishevelled to regulate $\beta$-Catenin signaling and osteoclastogenesis. J. Biol. Chem. 2010, 285, 14756-14763. [CrossRef] [PubMed]

114. Malbon, C.C. Frizzleds: New members of the superfamily of G-protein-coupled receptors. Front. Biosci. 2004, 9, 1048-1058. [CrossRef] [PubMed]

115. Cojoc, M.; Peitzsch, C.; Trautmann, F.; Polishchuk, L.; Telegeev, G.D.; Dubrovska, A. Emerging targets in cancer management: Role of the CXCL12/CXCR4 axis. Onco. Targets Ther. 2013, 6, 1347-1361. [PubMed]

116. Rosanò, L.; Bagnato, A. Endothelin therapeutics in cancer: Where are we? Am. J. Physiol. Regul. Integr. Comp. Physiol. 2016, 310, R469-R475. [CrossRef] [PubMed]

117. Dannenberg, A.J.; Subbaramaiah, K. Targeting cyclooxygenase-2 in human neoplasia: Rationale and promise. Cancer Cell 2003, 4, 431-436. [CrossRef]

118. Hull, M.A.; Ko, S.C.; Hawcroft, G. Prostaglandin EP receptors: Targets for treatment and prevention of colorectal cancer? Mol. Cancer Ther. 2004, 3, 1031-1039. [PubMed]

119. O'Callaghan, G.; Houston, A. Prostaglandin E2 and the EP receptors in malignancy: Possible therapeutic targets? Br. J. Pharmacol. 2015, 172, 5239-5250. [CrossRef] [PubMed]

120. Taub, J.S.; Guo, R.L.; Leeb-Lundberg, M.F.; Madden, J.F.; Daaka, Y. Bradykinin receptor subtype 1 expression and function in prostate cancer. Cancer Res. 2003, 63, 2037-2041. [PubMed]

121. Liu, Y.; An, S.; Ward, R.; Yang, Y.; Guo, X.X.; Li, W.; Xu, T.R. G protein-coupled receptors as promising cancer targets. Cancer Lett. 2016, 376, 226-239. [CrossRef] [PubMed]

(C) 2016 by the authors; licensee MDPI, Basel, Switzerland. This article is an open access article distributed under the terms and conditions of the Creative Commons Attribution (CC-BY) license (http://creativecommons.org/licenses/by/4.0/). 